\title{
NATURAL VALUES AS A BASIS FOR POSITIONING OF POLISH CITIES AND REGIONS
}

\begin{abstract}
Increasingly nowadays the image of brand is more important than the product's actual characteristics. Therefore, one of the most challenging tasks for contemporary brands is to become deeply embedded in the awareness of the marketing activities recipients. This situation takes also place in the case of the cities and regions that compete with each other in order to attract tourists, new citizens, students and investors. Territorial units may choose, among other things, from such distinctive characteristics (so-called unique selling proposition) as ecology and place-specific natural values. With regard to the above, the aim of this paper is to analyse the extent to which such attributes have been used in positioning of Polish territorial units. For that reason, the paper mentions symbols and promotional slogans of selected cities and all provinces (because for destinations the most essential positioning elements are: the place names, symbols and slogans). Furthermore, it refers also to the nature of positioning, as well as to the features and determinants of its efficiency. Another issue discussed in the paper concerns a group of people, which is susceptible to referring to ecology and natural values in promotional activities. Finally, the paper identifies the factors that decide whether the positioning based on the natural values of territorial units is effective or not.
\end{abstract}

Keywords: natural values, ecotourism, territorial marketing, an image of territorial unit, the positioning of cities and regions

\section{INTRODUCTION}

In the age of growing competition, territorial units seek unique features that would let them become distinctive in the minds of marketing activities recipients (including in particular tourists). Local authorities of some cities and the majority of provinces believe that the area in which the unique features of places can be found are their natural values. However, in order to make the positioning based on the elements of natural environment effective and consequently, to achieve intended marketing results, one has to adhere to specified principles. Therefore, the aim of this article is to identify the premises of creating effectively an "environmental" image of territorial units. What is more, the author's intention was to analyse graphic signs and promotional slogans of selected Polish cities and all provinces, taking into consideration direct references to the nature used in the signs and slogans. Such approach is concurrent with the belief that for destinations the most important positioning elements are the place name, a symbol, and a positioning slogan².

\footnotetext{
${ }^{1}$ Marcin Gębarowski, PhD, Department of Marketing, Faculty of Management, Rzeszow University of Technology, al. Powstańców Warszawy 8, 35-959 Rzeszów, tel. + 48 (17) 86514 74, e-mail: marcing@prz.edu.pl

${ }^{2}$ S. Pike, Destination Marketing. An Integrated Marketing Communication Approach. Butterworth-Heinemann, Burlington 2008, p. 229.
} 


\section{THE NATURE AND COMPLEXITY OF TERRITORIAL UNIT POSITIONING}

The concept of positioning is an important element of marketing strategies applied by all organisations, which, to a large extent, determines the ability to gain a competitive advantage. It also concerns those cities and regions which compete with each other in order to draw interest of the representatives of diverse groups that exist in the vicinity of the discussed cities and regions.

The literature on the subject, both foreign and domestic, offers many definitions of the notion in question. When attempting to generalise the definitions that have been proposed so far, the positioning is a strategic marketing operation which regards a particular sphere of partners, decision-makers - clients of various types of organisations, mental sphere. Performing specified marketing communication tasks - with regard to transmitting properly created marketing messages and monitoring their effects - helps organisations compete in order to make their own features and the benefits to the clients, which result from these features, to be perceived as unique in comparison to the competitors ${ }^{3}$.

Completing the positioning process in an appropriate manner entails taking complex actions and requires a lot of time. The most important positioning features can be specified as follows ${ }^{4}$ :

- it includes the level of organisation activity which aims at making its own product more distinctive than the competitive offers,

- it takes place in the awareness of purchasers and is a mental process,

- it is an activity related not only to the product, but also to the perception area of the recipients of marketing activities,

- it is a process of place identification in the purchasers' perception area, which ensures that a particular product has the strongest position as compared with market competitors,

- it is a part of product identity.

The positioning of products widely uses USP, i.e. unique selling proposition. Finding such an attribute contributes to the creation of a clear and positive image of an offer in the marketing activity recipients' minds. In the context of searching for a unique feature for a territorial unit, it is worth emphasising the fact that the brand of such unit may and should meet the rational (functional or utilitarian) and emotional needs. It should therefore offer something unique, which can become the reason of a strong emotional relationship with the recipient of the message. Hence the problem and the real challenge is to create such added value, which would be noticeable, accessible and simultaneously, in accordance with the reality ${ }^{5}$.

In the world of brands, the product image and positioning may be much more important than the place's actual characteristics ${ }^{6}$. This remark indicates the importance of a proper, strategic attitude of local authorities towards the positioning of cities and regions.

\footnotetext{
${ }^{3}$ A. Szromnik, Pozycjonowanie jako podstawa strategii marketingowej miast i regionów. Studia Ekonomiczne i Regionalne 2011, No 2, Vol. V, p. 6.

${ }^{4}$ J. Pogorzelski, Pozycjonowanie produktu. Polskie Wydawnictwo Ekonomiczne, Warszawa 2008, p. 17.

${ }^{5}$ M. Florek, A. Augustyn, Strategia promocji jednostek samorzadu terytorialnego - zasady i procedury. Fundacja Best Place - Europejski Instytut Marketingu Miejsc, Warszawa 2011, p. 13.

${ }^{6}$ E. Avraham, E. Ketter, Media Strategies for Marketing Places in Crisis. Improving the Image of Cities, Countries and Tourist Destinations. Butterworth-Heinemann, Burlington 2008, p. 16.
} 


\section{A GROUP OF RECIPIENTS OF MARKETING ACTIVITIES, SENSITIVE TO REFERRING TO NATURAL VALUES IN PROMOTIONAL SLOGANS}

Tourism is inextricably linked with the natural environment and depends on its quality. It is an area of activity, which is extremely flexible about the changes in the needs of people and in their way of thinking. Nowadays one can observe the development of new motifs relating to travelling by the tourists who are tired of everyday life in haste, noise and polluted environment, as well as who are more and more aware of the fact that it is necessary to protect the nature, whose resources run out each day. It is estimated that this phenomenon refers to one third of all travellers throughout the world - people who make a trip particularly for tourist purposes, in order to have a holiday, to enjoy heritage tourism, etc. $^{\text {p }}$

People who are extremely sensitive to the positioning based on natural values are especially those who are orientated towards cognitive tourism (including landscape tourism) and so-called ecotourism. The latter is also referred to as green tourism or nature tourism.

Ecotourism is a segment of sustainable tourism that offers experiences that enable visitors to discover natural areas while preserving their integrity, and to understand, through interpretation and education, the natural and cultural sense of place ${ }^{8}$. Ecotourism is usually typical of the areas which possess the highest natural and landscape values, and it directly contributes to the environment protection. People who participate in this form of travelling have strong ecological awareness and are very sensitive to the nature ${ }^{9}$. At the end of last century, the literature on the subject defined such people as green tourists or ecotourists. However, it is worth mentioning that the group described in this manner is not internally uniform (homogeneous). On the one hand, someone who belongs to it can be, for example, a staunch proponent of ecotourism, but on the other hand, a person who makes a long journey during which he or she is occasionally involved in the nature-based tourism could be also considered as a representative of the above-mentioned group ${ }^{10}$.

In order to determine the dominant motif for the territorial unit positioning, one has to specify target groups on which marketing activities will focus. In the case of the cities and regions that decide to highlight their natural attributes, the most significant group should therefore include the tourists who are extremely interested in the nature and ecology.

\section{AN EVALUATION OF THE USAGE OF NATURAL ENVIRONMENT AT- TRIBUTES IN THE PROMOTIONAL ACTIVITIES OF POLISH CITIES AND REGIONS}

Polish cities attempt to position themselves using diversified attributes. The analysis of logotypes and slogans of several dozens of cities has revealed that very few of them refer to the areas which are directly related to the natural environment. Among the cities which use promotional slogans indicating places that are tourist attractions, one should enumerate the following: Karpacz (Karpacz - a city under the Śnieżka Mountain, "Karpacz miasto pod Śnieżką"), Międzyzdroje (Międzyzdroje - the pearl of the Baltic Sea,

\footnotetext{
${ }^{7}$ D. Zaręba, Ekoturystyka, Wydawnictwo Naukowe PWN, Warszawa 2006, p. 34.

${ }^{8}$ C.R. Goeldner, J.B.R. Ritchie, Tourism. Principles, Practices, Philosophies, John Wiley \& Sons, Hoboken 2012, p. 386.

${ }^{9}$ D. Zaręba, Ekoturystyka..., op. cit., p. 53.

${ }^{10}$ D.A. Fennell, Ecotourism Programme Planning. CABI Publishing, Trowbridge 2002, pp. 16-17.
} 
"Międzyzdroje - perła Bałtyku”), Zakopane (Zakopane - the Tatras can't be any closer, „Zakopane - najbliżej Tatr”), Wisła (Wisła - the pearl of the Beskids, "Wisła - perła Beskidów"), Głuszyca (Gtuszyca. The heart of the Sudetes nature, "Gmina Głuszyca. Serce sudeckiej natury"), Nidzica (Nidzica - the gate to Warmia-Masuria, "Nidzica brama na Warmię i Mazury”), Bytów (Bytów. The city in Kashubia „Bytów. Miasto na Kaszubach"). There are also cities which allude to their unique location - for example Świnoujście (Świnoujście. The land of 44 islands, "Świnoujście. Kraina 44 wysp") and Szczecin (Floating garden, "Pływający ogród"), and cities which - in regard to their distinctive features - consider climatic conditions to be relevant, like for instance Tarnów (Tarnów - the Polish pole of warmth, "Tarnów - polski biegun ciepła") and Gdynia (Gdynia - a sunny city with temperament, "Gdynia - słoneczne miasto $\mathrm{Z}$ temperamentem").

There are very few examples of territorial units that, in connection with the idea of positioning, refer directly to the nature, such as Olsztyn (Natural garden, "O!gród z natury") and Krasnystaw (Naturally!, "Naturalnie!"). Similarly, only few urban settlements endeavour to relate its image to the ecology. Such examples include Otwock (with a slogan Otwock - a green city, "Otwock - zielone miasto") and Racibórz. And although the latter does not use any promotional slogan, the graphic sign of the city emphasises the natural values of the territorial unit. There is a green leaf with an "ISO 14001" mark, which is located next to one of the letters that form the logotype. It informs that Raciborz - as the first city in Europe - was awarded the Certificate in Environmental Management according to the ISO 14001 standard.

In contrast with the above, many Polish provinces refer in the elements of their brands to the natural values. This fact is supported by advertising slogans and graphic signs created for the purpose of promotional activities that are taken by the provinces (table 1).

Table 1. Advertising slogans and symbols of Polish provinces

\begin{tabular}{|c|c|c|c|}
\hline Province & Advertising slogan & Slogan - original version & Symbol \\
\hline $\begin{array}{l}\text { Lower Silesia } \\
\text { Province }\end{array}$ & $\begin{array}{c}\text { Lower Silesia. } \\
\text { Difficult to talk about - } \\
\text { easy to see around }\end{array}$ & $\begin{array}{c}\text { „Dolny Śląsk. } \\
\text { Nie do opowiedzenia. } \\
\text { Do zobaczenia" }\end{array}$ & $\begin{array}{l}\text { NY } \\
\text { SK }\end{array}$ \\
\hline $\begin{array}{l}\text { Kujawy- } \\
\text { Pomerania } \\
\text { Province }\end{array}$ & Our Kujawy-Pomerania & $\begin{array}{c}\text { "Nasze kujawsko- } \\
\text { pomorskie" }\end{array}$ & \\
\hline Lublin Province & Lubelskie. Taste life! & $\begin{array}{l}\text { „Lubelskie. } \\
\text { Smakuj życie!” }\end{array}$ & $\begin{array}{l}\text { skie } \\
\text { ẏzycie! }\end{array}$ \\
\hline $\begin{array}{l}\text { Lubuskie } \\
\text { Province }\end{array}$ & $\begin{array}{l}\text { Lubuskie - wor- } \\
\text { th your while }\end{array}$ & $\begin{array}{l}\text { "Lubuskie - } \\
\text { warte zachodu" }\end{array}$ & $\begin{array}{l}\text { sskie } \\
\text { schoou }\end{array}$ \\
\hline Łódź Province & Łódzkie speeds up & $\begin{array}{l}\text { „Łódzkie nabiera } \\
\text { prędkości” }\end{array}$ & zkkie \\
\hline $\begin{array}{l}\text { Lesser Poland } \\
\text { Province }\end{array}$ & - & - & \\
\hline $\begin{array}{l}\text { Mazovia } \\
\text { Province }\end{array}$ & $\begin{array}{c}\text { Mazovia- } \\
\text { the heart of Poland }\end{array}$ & $\begin{array}{l}\text { „Mazowsze - } \\
\text { serce Polski”" }\end{array}$ & NSze. \\
\hline
\end{tabular}




\begin{tabular}{|c|c|c|c|}
\hline Opole Province & - & - & \\
\hline $\begin{array}{l}\text { Podkarpackie } \\
\text { Province }\end{array}$ & $\begin{array}{l}\text { Podkarpackie. } \\
\text { The open space }\end{array}$ & $\begin{array}{l}\text { „Podkarpackie. } \\
\text { Przestrzeń otwarta" }\end{array}$ & PODKARPACKIE \\
\hline Podlasie Province & $\begin{array}{l}\text { Podlasie. Wealth } \\
\text { of diversity }\end{array}$ & $\begin{array}{l}\text { „Podlaskie. } \\
\text { Bogactwo różnorodności” }\end{array}$ & \\
\hline $\begin{array}{l}\text { Pomerania } \\
\text { Province }\end{array}$ & $\begin{array}{l}\text { Pomorskie- } \\
\text { a good course }\end{array}$ & „Pomorskie - dobry kurs” & \\
\hline Silesia Province & Silesia. Positive energy & $\begin{array}{l}\text { „Śląskie. } \\
\text { Pozytywna energia” }\end{array}$ & $\begin{array}{l}\text { Slaskie. } \\
\text { Pozytywa energia }\end{array}$ \\
\hline $\begin{array}{l}\text { Świętokrzyskie } \\
\text { Province }\end{array}$ & $\begin{array}{l}\text { Świętokrzyskie enchants. } \\
\quad \text { Come on weekend }\end{array}$ & $\begin{array}{l}\text { „Świętokrzyskie czaruje. } \\
\text { Poleć na weekend”" }\end{array}$ & rryskie \\
\hline $\begin{array}{l}\text { Warmia-Masuria } \\
\text { Province }\end{array}$ & $\begin{array}{c}\text { Masuria - The wonder } \\
\text { of nature }\end{array}$ & „Mazury cud natury” & $\begin{array}{ll}\text { UAt } \\
\text { RY. }\end{array}$ \\
\hline $\begin{array}{l}\text { Wielkopolska } \\
\text { Province }\end{array}$ & $\begin{array}{c}\text { Wielkopolska. Fascinat- } \\
\text { ing history. Exciting } \\
\text { adventure. }\end{array}$ & $\begin{array}{c}\text { „Wielkopolska. Wielka } \\
\text { historia. Wielka przygoda” }\end{array}$ & wielkop \\
\hline $\begin{array}{l}\text { West Pomerania } \\
\text { Province }\end{array}$ & $\begin{array}{l}\text { Zachodniopomorskie. } \\
\text { Sea of adventure }\end{array}$ & $\begin{array}{l}\text { „Zachodniopomorskie. } \\
\text { Morze przygody” }\end{array}$ & \\
\hline
\end{tabular}

Source: own elaboration (promotional slogans and graphic signs have been taken from the websites of province offices or other websites related to them).

The most overt reference to the nature can be found in the slogan which promotes Warmia-Masuria Province (Masuria - The wonder of nature, "Mazury cud natury"). Additionally, elements and colours presented in the graphic sign of this region refer to the natural resources (according to the authors of the logotype, its colours symbolise as follows: yellow - the sun, green - forests, and light blue - lakes). Slogans and graphic signs of other provinces also refer to the natural environment, yet these references are not so explicit. For example, the slogan of West Pomerania Province (Zachodniopomorskie. Sea of adventure, "Zachodniopomorskie. Morze przygody") directly refers to sea, an attribute

\footnotetext{
${ }^{11}$ Polish slogan „Świętokrzyskie czaruje. Poleć na weekend” is a pun, in which one can easily decipher the hidden meaning - czaruje (enchants) may indicate that the province either enchants with its natural beauty or, figuratively, uses magic on tourists (the association with witches, for which the province was famous in the past - even its logotype represents a witch on a broomstick).
} 
of the province. The slogan implies also the multiplicity of attractions and events which the region offers, and a symbol, which represents an outline of the coastline and seagulls, complements the slogan. A logotype of Lower Silesia Province comprises three squares with motifs that allude to various kinds of tourism - cultural, mountain and health-resort. Their basis are, among other things, natural attractions of the region. A sign, which identifies Lesser Poland Province, is composed of an orange square in the background and a light blue object in the foreground, which represents the summit of the Tatra Mountains. Below the summit one can notice a ribbon - a representation of the Vistula River - that goes to the bottom of the sign. According to the authors of a Lubuskie Province logotype, its colours have associations with forests, fields, rivers and lakes. The nature and fresh air have been attributed to this sign, as they are typical of the western border region of Poland. A concept paper relating to promotional activities of Podkarpackie Province indicates that the strongest brand of this region are Bieszczady Mountains [Strategia kreacji i promocji... 2010]. This fact has been reflected in a logotype and promotional slogan of the region. The same elements of the brand have to evoke association with aviation industry, which is second - economic - distinctive feature of Podkarpackie Province. An element of the symbol, which is green, refers to the nature of Bieszczady mountain pastures, and the blue one symbolises a trace left on the sky by aeroplanes. Furthermore, the slogan Podkarpackie. The open space ("Podkarpackie. Przestrzen otwarta") connotes Bieszczady Mountains, as well as the aviation.

In the context of the analysed problems, Lubuskie Province is distinguished by its subbrand naturally Lubuskie (,naturalnie Lubuskie”), which occurs next to other components of the territorial brand of the region: young Lubuskie („młode Lubuskie"), WE create Lubuskie („tworzyMY Lubuskie”), wholesome Lubuskie (,zdrowe Lubuskie”). The subbrand, which refers to the nature, is intended to create the awareness of natural resources of the province among its inhabitants.

It must be mentioned that the analysed graphic signs and slogans have been adopted by the authorities of the provinces (frequently in concept papers, called brand books, visual identity guides, etc.) for a longer period of time. However, there are still undertaken single promotional campaigns which refer strongly to the natural attributes of individual Polish regions. A four-month campaign, The eternal need for nature - Podlaskie ("Odwieczna potrzeba natury - Podlaskie"), which was initiated in April 2012, is such an example. One of its elements was to broadcast an advertising film on Discovery channels, in which the multicultural nature of the region and unique natural values of the province were highlighted.

\section{CONCLUSIONS}

Polish cities and regions, to a small extent, endeavour to base the positioning concept on the natural values. It must be noticed that the references to the attributes of natural environment are more often conspicuous in long-term image-related actions taken by the regions, rather than in the case of urban settlements. This situation results from the fact that the provinces, covering vast areas, are much more diverse - and therefore there are more distinctive features (including also those related to the natural environment), to which one can refer in the marketing actions.

Only very few urban settlements manage to evoke nature-related associations using their own images. However, also for those urban settlements which decided to search for 
unique characteristics in other areas (which are different to the natural ones) it is difficult to become distinctive compared to the competitors. The most frequently committed error is a lack of the original positioning concept, which results in expressing the essence of brand in a similar manner. Consequently, the cities face difficulties in becoming deeply embedded in the awareness of the recipients of marketing activities. For example, there are urban settlements that attempt to position themselves as "the capitals" in diversified contexts - like Rzeszów (Rzeszów. The capital of innovation, "Rzeszów. Stolica innowacji"), Opole (Opole - the capital of Polish song, "Opole - stolica polskiej piosenki"), Stalowa Wola (Stalowa Wola - the bilberry capital of Poland, "Stalowa Wola - jagodowa stolica Polski”), Złotoryja (Złotoryja - the capital of Polish gold, "Złotoryja stolica polskiego złota"), Sulęcin (Sulęcin - the bicycle capital of Lubuskie Province, "Sulęcin - rowerowa stolica ziemi lubuskiej"). A similar behaviour can be observed in the case of the cities which refer to the opportunities that they offer - for instance: Zabrze (Zabrze - a mine of possibilities, "Zabrze - kopalnia możliwości”), Gubin (Gubin. A mosaic of opportunities, "Gubin. Mozaika możliwości”), Kędzierzyn-Koźle (Kędzierzyn-Koźle. A city of opportunities, "Kędzierzyn-Koźle. Miasto możliwości"). There are, however, also positive examples of positioning slogans, which can be regarded as the quintessence of distinctiveness, creativity and pun - like Toruń. Get Gothic ("Torun. Gotyk na dotyk") ${ }^{12}$, Cieszyn - Enjoy the city ("Cieszyn - Ciesz się Cieszynem") "13, Rybnik. A city with spirit ("Rybnik. Miasto z ikrą")"

In the light of the analyses that have been conducted, one can indicate the factors which have an impact upon the effectiveness of territorial unit positioning based on natural values. Regarding such determinants, one should take into account the following:

- ensuring that marketing personnel of city halls and province offices has knowledge of place positioning or using the services of an outside entity that specialise in providing strategic solutions in respect of territorial marketing,

- perceiving the positioning as an activity that involves great commitment - including both financial outlays and labour amount,

- emphasising natural unique features of a region consistently and coherently, in respect of all marketing activities,

- basing the idea of positioning on marketing research results that refer to a current and intended image of a territorial unit,

- orienting oneself to a specified target audience (recipients of marketing activities who are sensitive to referencing to natural attributes),

- looking for one's own, unique idea for making a place distinctive - deciding not to copy solutions used by other territorial units,

- creating a unique selling proposition (USP) according to real (and not imaginary) attributes of a city or region,

- generating citizens' support for the idea of positioning which has been chosen.

\footnotetext{
${ }^{12}$ Polish slogan "Toruń. Gotyk na dotyk" contains words - gotyk (gothic) and dotyk (a touch), which rhyme with each other.

${ }^{13}$ Polish slogan "Cieszyn - Ciesz się Cieszynem” represents a play on words, in which Cieszyn (a proper name, the city in southern Poland) sounds similarly to the words Ciesz się (enjoy) and Cieszynem (the instrumental case of the noun).

${ }^{14}$ Polish slogan "Rybnik. Miasto z ikrą" is a pun, since Rybnik (a city in Silesia Province), whose name connotes ryba (a fish), creates an amusing relationship with the word ikra (spawn = the eggs of fish). Additionally, the Polish phrase "Miasto z ikrą" means A city with spirit.
} 
A proper positioning is a relevant element of effective city or region brand management. As the market practice proves - the positioning can be based on natural attributes. However, in order to make this action effective, it must be implemented in a well-thoughtout manner, regarding the above-mentioned determinants of territorial brand positioning.

\section{REFERENCES}

[1] Avraham E., Ketter E., Media Strategies for Marketing Places in Crisis. Improving the Image of Cities, Countries and Tourist Destinations, Butterworth-Heinemann, Burlington 2008.

[2] Fennell D.A., Ecotourism Programme Planning, CABI Publishing, Trowbridge 2002.

[3] Florek M., Augustyn A., Strategia promocji jednostek samorzadu terytorialnego - zasady $i$ procedury, Fundacja Best Place - Europejski Instytut Marketingu Miejsc, Warszawa 2011.

[4] Goeldner C.R., Ritchie J.B.R., Tourism. Principles, Practices, Philosophies, John Wiley \& Sons, Hoboken 2012.

[5] Pike S., Destination Marketing. An Integrated Marketing Communication Approach, Butterworth-Heinemann, Burlington 2008.

[6] Pogorzelski J., Pozycjonowanie produktu, Polskie Wydawnictwo Ekonomiczne, Warszawa 2008.

[7] Strategia kreacji i promocji marki województwa podkarpackiego z planem wdrożenia strategii w latach 2010-2015 oraz wytycznymi do strategii, 2010 (http://www.wrota.podkarpackie.pl/ res/um/region/podkarpackie_rozwiazanie_strategiczne_.pdf).

[8] Szromnik A., Pozycjonowanie jako podstawa strategii marketingowej miast i regionów, "Studia Ekonomiczne i Regionalne" 2011, No 2, Vol. V, pp. 5-13.

[9] Zaręba D., Ekoturystyka, Wydawnictwo Naukowe PWN, Warszawa 2006.

\section{WALORY PRZYRODNICZE JAKO PODSTAWA POZYCJONOWANIA POLSKICH MIAST I REGIONÓW}

Obecnie coraz częściej wizerunek marki jest ważniejszy od rzeczywistych cech produktu. Zajęcie wyrazistego miejsca $\mathrm{w}$ świadomości adresatów działań marketingowych staje się zatem jednym z głównych wyzwań dla współczesnych marek. Taka sytuacja ma miejsce również w przypadku miast i regionów, rywalizujących między sobą o przyciągnięcie turystów, nowych mieszkańców, studentów lub inwestorów. Dla jednostek terytorialnych jednym z możliwych obszarów poszukiwania wyróżników (tzw. unikalnej propozycji sprzedaży) jest ekologia oraz wyjątkowe walory przyrodnicze. W związku z tym w artykule poddano analizie zakres wykorzystania tych atrybutów przy pozycjonowaniu polskich jednostek terytorialnych. W tym celu przywołano symbole oraz hasła promocyjne wybranych miast oraz wszystkich województw (dla nich bowiem najważniejszymi elementami pozycjonowania są: nazwy, symbole i slogany). Odniesiono się także do istoty samego pozycjonowania oraz cech i determinant jego skuteczności. Scharakteryzowano grupę osób, która jest podatna na odwoływanie się w działaniach promocyjnych do ekologii i walorów przyrodniczych W podsumowaniu zidentyfikowano czynniki decydujące o skuteczności pozycjonowania, opartego na wykorzystywaniu przyrodniczych atrybutów jednostek terytorialnych.

Słowa kluczowe: walory przyrodnicze, ekoturystyka, marketing terytorialny, wizerunek jednostki terytorialnej, pozycjonowanie miast i regionów

DOI: 10.7862/rz.2013.mmr.29

Tekst złożono w redakcji: wrzesień 2013

Przyjęto do druku: wrzesień 2013 